\title{
ОБҐРУНТУВАННЯ ВИБОРУ ДОПОМІЖНИХ РЕЧОВИН ДЛЯ ОДЕРЖАННЯ ТАБЛЕТОК НА ОСНОВІ ЕКСТРАКТІВ МАЛЬВИ ЛІСОВОЇ І ПОДОРОЖНИКА ЛАНЦЕТОЛИСТОГО
}

\author{
(С). Я. Белей ${ }^{1}$, Т. А. Грошовий ${ }^{2}$, Н. М. Белей ${ }^{2}$ \\ ТОВ «Тернофрарм» ${ }^{1}$, Тернопіль \\ ДВНЗ «Тернопільський державний медичний університет імені І. Я. Горбачевського \\ мО3 України»² \\ beley@tdmu.edu.ua
}

\begin{abstract}
Мета роботи. Вивчити вплив фрармацевтичних фракторів на деякі показники якості таблеток із метою вибору кращих допоміжних речовин (ДР) для розробки складу і технології нового комбінованого таблетованого лікарського засобу на основі сухих екстрактів мальви лісової і листя подорожника ланцетолистого методом вологої грануляції.

Матеріали і методи. Основні діючі речовини - сухі екстракти мальви лісової та листя подорожника ланцетолистого, 16 ДР, об'єднаних в 4 групи фрармацевтичних фракторів.

Таблетки отримували методом вологої грануляції. Дослідження впливу ДР на такі показники, як однорідність маси таблеток, їх стираність та стійкість до роздавлювання, а також розпадання таблеток проводили відповідно до вимог ДФУ, 2 видання. Також вивчали залежність стійкості таблеток до вологи від виду ДР в їх складі.

Результати й обговорення. У статті вивченно вплив фармацевтичних фракторів на деякі показники якості таблеток на основі сухих екстрактів мальви лісової і листя подорожника ланцетолистого. За допомогою чотирифакторного експерименту - греко-латинської квадрату встановлено вплив 4-х якісних фракторів на основні показники якості таблеток на основі сухих екстрактів мальви лісової і подорожника ланцетолистого. Побудовано ранжовані ряди переваг для впливу допоміжних речовин на 6 відгуків (показників якості таблеток). Вивчено вплив 16-ти допоміжних речовин на однорідність маси таблеток, їх стираність і стійкість до роздавлювання, а також розпадання і стійкість таблеток до вологи.

Висновки. На основі отриманих результатів обрано кращі допоміжні речовини для розробки складу та технології нового комбінованого таблетованого лікарського засобу на основі сухих екстрактів мальви лісової і листя подорожника ланцетолистного методом вологої грануляції, а саме: МКЦ 101, поліплаздон XL-10, натрію карбоксиметилкрохмаль, кремнію діоксид колоїдний, неусилін US-25, 5 \% крохмальний клейстер.
\end{abstract}

Ключові слова: фрармацевтичні фрактори; допоміжні речовини; показники якості; таблетки; екстракти мальви лісової і подорожника ланцетолистого.

Вступ. Перспективною комбінацією для лікування кашлю при простудних захворюваннях $€$ поєднання екстрактів подорожника ланцетолистого і мальви лісової у фрормі таблеток, оскільки це дозволить поєднати протизапальну, відхаркувальну, знеболюючу та імуномодулюючу дії подорожника і мальви в одній лікарській фрормі [2-5].

Матеріали і методи. Основні діючі речовини сухі екстракти мальви лісової та листя подорожника ланцетолистого, 16 ДР, об'єднаних в 4 групи фрармацевтичних фракторів.

Таблетки отримували методом вологої грануляції. Дослідження впливу ДР на такі показники, як однорідність маси таблеток, їх стираність та стійкість до роздавлювання, а також розпадання таблеток проводили відповідно до вимог ДФУ, 2 видання [6].

Також вивчали залежність стійкості таблеток до вологи від виду ДР у їх складі. Для цього до- сліджувані взірці таблеток зважували і поміщали в ексикатор над насиченим розчином натрій сульфрату при температурі $25^{\circ} \mathrm{C}$. Через 1, 2 та 3 доби відбирали досліджувані зразки, зважували і досліджували їх за зовнішнім виглядом. 3 різницею маси до і після експерименту робили висновок про здатність таблеток вбирати вологу. Результат поглинання вологи таблетками виражали у відсотках.

Результати й обговорення. Таблетки на основі сухих екстрактів мальви лісової і подорожника ланцетолистого було одержано методом вологої грануляції. До складу таблеток вводили наповнювачі, розпушувачі, регулятори вологи і зв'язуючі речовини. Перелік ДР (фракторів та їх рівнів), які вивчали при розробці складу і технології таблеток на основі сухих екстрактів мальви лісової та подорожника ланцетолистого, наведено в таблиці 1.

ISSN 2312-0967. Pharmaceutical review. 2018. № 3 
Фармацевтична технологія, біофармація, гомеопатія Pharmaceutical technology, biopharmacy, homeopathy

Таблиця 1. Фактори та їх рівні, які вивчали при створенні таблеток на основі сухих екстрактів мальви лісової та подорожника ланцетолистого

\begin{tabular}{|c|c|}
\hline Фактори & Рівні фракторів \\
\hline Фактор А - наповнювачі & $\begin{array}{l}\mathrm{a}_{1} \text { - сахароза } \\
\mathrm{a}_{2} \text { - лактози моногідрат } \\
\mathrm{a}_{3} \text { - мікрокристалічна целюлоза (МКЦ) } 101 \\
\mathrm{a}_{4} \text { - мікрокристалічна целюлоза МКЦ } 102\end{array}$ \\
\hline Фактор В - розпушувачі & $\begin{array}{l}\mathrm{b}_{1}-\text { крохмаль картопляний } \\
\mathrm{b}_{2}-\text { поліплаздон XL-10 } \\
\mathrm{b}_{3} \text { - натрію кроскармелоза } \\
\mathrm{b}_{4}-\text { натрію карбоксиметилкрохмаль }\end{array}$ \\
\hline Фактор C - регулятори вологи & $\begin{array}{l}\mathrm{c}_{1}-\text { магнію карбонат легкий } \\
\mathrm{c}_{2}-\text { кремнію діоксид колоїдний безводний } \\
\mathrm{c}_{3} \text { - неусилін US-2 } \\
\mathrm{c}_{4}-\text { неусилін UFL-2 }\end{array}$ \\
\hline Фактор D - зв'язуючі речовини & $\begin{array}{l}\mathrm{d}_{1}-5 \text { \% крохмальний клейстер } \\
\mathrm{d}_{2}-5 \text { \% розчин метилцелюлози (МЦ) - } 15 \\
\mathrm{~d}_{3}-5 \text { \% спиртовий (80 \% спирт) розчин гідроксипропілметилцелюлози (ГПМЦ) } \\
\mathrm{d}_{4}-5 \% \text { спиртовий розчин плаздону К-25 }\end{array}$ \\
\hline
\end{tabular}

Для вивчення впливу чотирьох фракторів та їх рівнів на основні показники якості таблеток на основі сухих екстрактів мальви лісової і подорожника ланцетолистого використали 4x4 греко-ла- тинський квадрат [7]. Матриця планування експерименту та результати дослідження таблеток на основі екстрактів мальви і подорожника наведено в таблиці 2.

Таблиця 2. Чотирифакторний експеримент на основі греко-латинського квадрату та результати дослідження показників якості таблеток на основі сухих екстрактів мальви лісової та листя подорожника ланцетолистого

\begin{tabular}{|c|c|c|c|c|c|c|c|c|c|c|c|c|c|c|c|c|}
\hline \multirow{2}{*}{$\begin{array}{l}\text { № } \\
\text { cepiï }\end{array}$} & \multicolumn{4}{|c|}{ Фактори } & \multicolumn{12}{|c|}{ Відгуки (показники якості таблеток) } \\
\hline & A & $\mathrm{B}$ & C & $\mathrm{D}$ & $\mathrm{y}_{7}$ & $\mathrm{y}_{7}^{\prime}$ & $\mathrm{y}_{8}$ & $\mathrm{y}_{8}{ }^{\prime}$ & $\mathrm{y}_{9}$ & $\mathrm{y}_{9}^{\prime}$ & $\mathrm{y}_{10}$ & $\mathrm{y}_{10}{ }^{\prime}$ & $\mathrm{y}_{11}$ & $\mathrm{y}_{11}^{\prime}$ & $\mathrm{D}$ & $D^{\prime}$ \\
\hline 1 & $a_{1}$ & $b_{1}$ & $\mathrm{C}_{1}$ & $\mathrm{~d}_{1}$ & 2,03 & 2,60 & 0,11 & 0,15 & 115,2 & 125,6 & 19,0 & 19,4 & 10,03 & 10,31 & 0,548 & 0,347 \\
\hline 2 & $a_{1}$ & $b_{2}$ & $\mathrm{C}_{2}$ & $d_{4}$ & 1,47 & 1,21 & 0,21 & 0,17 & 101,1 & 111,9 & 24,0 & 20,0 & 10,80 & 10,68 & 0,662 & 0,700 \\
\hline 3 & $a_{1}$ & $b_{3}$ & $\mathrm{C}_{3}$ & $\mathrm{~d}_{2}$ & 4,69 & 4,13 & 0,28 & 0,22 & 107,8 & 99,4 & 21,0 & 23,0 & 9,43 & 9,01 & 0,346 & 0,395 \\
\hline 4 & $a_{1}$ & $b_{4}$ & $\mathrm{C}_{4}$ & $d_{3}$ & 3,66 & 4,72 & 0,13 & 0,09 & 126,6 & 133,8 & 23,0 & 20,4 & 9,68 & 094 & 0,466 & 0,301 \\
\hline 5 & $a_{2}$ & $b_{1}$ & $\mathrm{C}_{2}$ & $d_{3}$ & 4,68 & 4,74 & 0,12 & 0,14 & 90,7 & 77,7 & 31,0 & 40,4 & 6,23 & 6,49 & 0,511 & 0,508 \\
\hline 6 & $a_{2}$ & $b_{2}$ & $\mathrm{C}_{1}$ & $\mathrm{~d}_{2}$ & 3,21 & 3,65 & 0,24 & 0,16 & 103,2 & 98,2 & 33,0 & 27,0 & 6,23 & 6,37 & 0,617 & 0,727 \\
\hline 7 & $a_{2}$ & $b_{3}$ & $\mathrm{C}_{4}$ & $\mathrm{~d}_{4}$ & 1,77 & 1,60 & 0,09 & 0,13 & 66,3 & 73,3 & 31,2 & 26,2 & 6,24 & 5,96 & 0,726 & 0,467 \\
\hline 8 & $a_{2}$ & $b_{4}$ & $\mathrm{C}_{3}$ & $\mathrm{~d}_{1}$ & 3,79 & 3,97 & 0,07 & 0,11 & 142,8 & 149,2 & 26,0 & 31,4 & 5,20 & 5,28 & 0,815 & 0,784 \\
\hline 9 & $a_{3}$ & $b_{1}$ & $\mathrm{C}_{3}$ & $\mathrm{~d}_{4}$ & 1,20 & 1,34 & 0,16 & 0,10 & $0<, 4$ & 55,2 & 52,0 & 60,0 & 6,48 & 6,34 & 0,489 & 0,469 \\
\hline 10 & $a_{3}$ & $b_{2}$ & $\mathrm{C}_{4}$ & $\mathrm{~d}_{1}$ & 1,40 & 1,82 & 0,07 & 0,03 & 120,9 & 109,7 & 74,0 & 69,4 & 6,71 & 6,41 & 0,776 & 0,839 \\
\hline 11 & $a_{3}$ & $b_{3}$ & $\mathrm{C}_{1}$ & $d_{3}$ & 2,07 & 2,14 & 0,03 & 0,07 & 67,2 & 71,0 & 81,5 & 74,5 & 6,59 & 6,75 & 0,612 & 0,714 \\
\hline 12 & $a_{3}$ & $b_{4}$ & $\mathrm{C}_{2}$ & $d_{2}$ & 1,58 & 1,68 & 0,03 & 0,07 & 71,8 & 76,2 & 23,2 & 28,2 & 7,12 & 6,98 & 0,849 & 0,882 \\
\hline 13 & $a_{4}$ & $b_{1}$ & $\mathrm{C}_{4}$ & $\mathrm{~d}_{2}$ & 1,81 & 1,77 & 0,07 & 0,03 & 65,8 & 61,4 & 51,0 & 59,6 & 6,44 & 6,74 & 0,614 & 0,570 \\
\hline 14 & $a_{4}$ & $b_{2}$ & $\mathrm{C}_{3}$ & $d_{3}$ & 1,98 & 2,11 & 0,03 & 0,07 & 98,9 & 89,5 & 75,0 & 69,0 & 6,98 & 7,12 & 0,765 & 0,805 \\
\hline 15 & $a_{4}$ & $b_{3}$ & $\mathrm{C}_{2}$ & $\mathrm{~d}_{1}$ & 1,44 & 1,32 & 0,07 & 0,03 & 64,1 & 72,1 & 19,0 & 23,0 & 6,98 & 6,70 & 0,739 & 0,775 \\
\hline 16 & $a_{4}$ & $b_{4}$ & $\mathrm{C}_{1}$ & $\mathrm{~d}_{4}$ & 1,26 & 1,20 & 0,27 & 0,37 & 55,6 & 58,8 & 63,0 & 57,0 & 6,85 & 6,71 & 0,556 & 0,403 \\
\hline
\end{tabular}

Примітка 1: $y_{7}$ і $\mathbf{y}_{7}^{\prime}-$ однорідність маси таблеток, $\pm \%$;

Примітка 2: $\mathrm{y}_{8}$ і $\mathrm{y}_{9}{ }^{\prime}$ - стираність таблеток, \%;

Примітка 3: $\mathrm{y}_{9}$ і у ${ }_{9}^{\prime}$ - стійкість таблеток до роздавлювання, $\mathrm{H}$;

Примітка 4: $\mathrm{y}_{10}$ і $\mathrm{y}_{10}^{\prime}$ - розпадання таблеток, хв;

Примітка 5: $\mathrm{y}_{11}$ і $\mathrm{y}_{11}{ }^{\prime}-$ стійкість таблеток до вологи, \%;

Примітка 6: D i D' - фрункція бажаності;

Примітка 7: перші шість відгуків $\left(\mathrm{y}_{1}-\mathrm{y}_{6}\right)$ описано в попередній публікації [1].

ISSN 2312-0967. Фармацевтичний часопис. 2018. № 3 
Для статистичної обробки отриманих результатів використовували дисперсійний аналіз, а саме схему чотирифакторного експерименту.

Необхідно було визначити, від якої групи ДР найбільше залежать показники якості досліджуваних таблеток. Для відображення їх впливу будували ранжовані ряди переваг, в яких якісні фрактори розміщували у послідовності, що залежить від величини їх впливу на вивчений показник.

Вплив вивчених фракторів на однорідність маси таблеток $\left(\mathrm{y}_{7}\right)$ можна проілюструвати наступним рядом переваг: A > D > res > C > B. Вплив найбільш значущого фрактора A, а саме природи наповнювачів, на однорідність маси таблеток, відображено за допомогою діаграм на рисунку 1.

Згідно з даними рисунка 1, найкращі результати однорідності маси таблеток отримано при використанні в якості наповнювачів МКЦ 102 ( $\pm 1,61 \%)$ та МКЦ 101 ( $\pm 1,65 \%)$ відповідно ці дві речовини мають істотну перевагу над іншими наповнювачами, а саме сахарозою $( \pm 3,06 \%)$ і лактози моногідратом ( $\pm 3,43 \%)$.

Серед досліджених зв'язуючих речовин за позитивним впливом на однорідність маси таблеток на першому місці стояв 5 \% розчин плаздону К-25
Фармацевтична технологія, біофармація, гомеопатія Pharmaceutical technology, biopharmacy, homeopathy

$( \pm 1,38 \%)$, який мав перевагу над $5 \%$ крохмальним клейстером $( \pm 2,30 \%), 5$ \% розчином МЦ-15 ( $\pm 2,82 \%)$ та 5 \% спиртовим розчином ГПМЦ ( $\pm 3,26 \%)$.

Для впливу регуляторів вологи на однорідність маси досліджуваних таблеток було одержано такий ряд переваг: кремнію діоксид колоїдний безводний $( \pm 2,26 \%)$, за ним розташувався - магнію карбонат легкий ( $\pm 2,27$ \%) і неусилін UFL-2 ( $\pm 2,32 \%)$, які мали перевагу над неусиліном US-2 ( $\pm 2,90 \%)$.

Ряд переваг для розпушувачів за їх впливом на однорідність маси таблеток має такий вигляд: поліплаздон XL-10 ( $\pm 2,11 \%)$, натрію кроскармелоза $( \pm 2,40 \%)$, крохмаль картопляний $( \pm 2,52 \%)$, натрію карбоксиметилкрохмаль ( $\pm 2,73 \%)$.

Ранжований ряд переваг якісних фракторів за впливом на стираність таблеток $\left(\mathrm{y}_{8}\right)$ має такий вигляд: $\mathrm{D}>$ res >A > C. Фактор В за результатами статистичної обробки виявився статистично незначущим. Вплив найбільш значущого фрактора D, а саме зв'язуючих речовин, на стираність таблеток на основі екстрактів мальви лісової і подорожника ланцетолистого відображено за допомогою діаграм на рисунку 2.

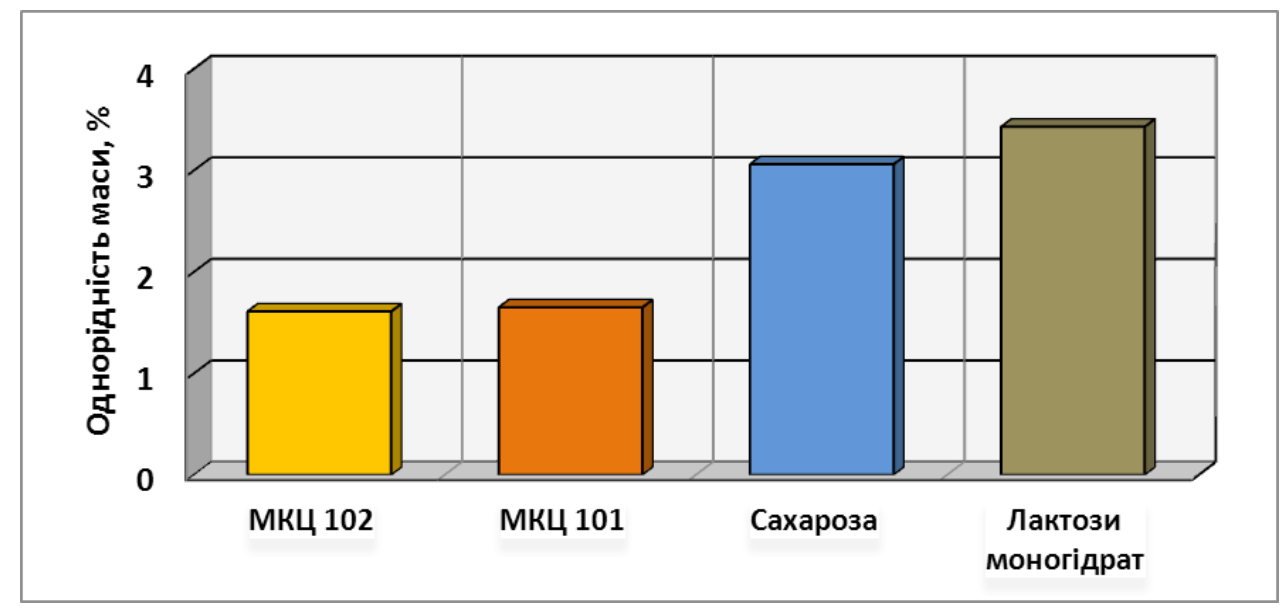

Рис. 1. Вплив наповнювачів на однорідність маси таблеток на основі екстрактів мальви лісової і подорожника ланцетолистого.

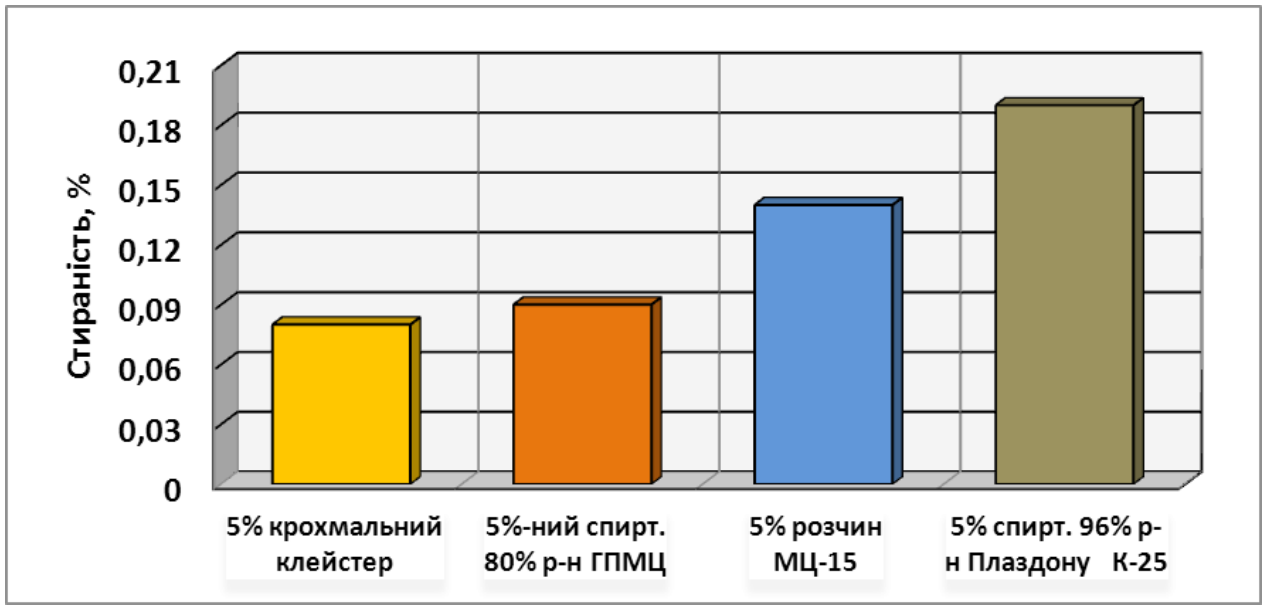

Рис. 2. Вплив зв'язуючих речовин на стираність таблеток на основі екстрактів мальви лісової і подорожника ланцетолистого.

ISSN 2312-0967. Pharmaceutical review. 2018. № 3 
Фармацевтична технологія, біофармація, гомеопатія Pharmaceutical technology, biopharmacy, homeopathy

3 даних рисунка 2 видно, що найбільш стійкими до стирання були серії, в яких як зволожувачі використовували $5 \%$ крохмальний клейстер (0,08\%) та $5 \%$ спиртовий розчин ГПМЦ (0,09\%), які мали перевагу над 5 \% розчином МЦ-15 (0,14 \%) та 5 \% спиртовим розчином плаздону К-25 (0,19\%).

Вплив наповнювачів на стираність досліджуваних таблеток можна проілюструвати таким рядом переваг: МКЦ 101 (0,07 \%), МКЦ 102 (0,12\%), лактози моногідрат $(0,13 \%)$, сахароза $(0,17 \%)$.

Серед вивчених регуляторів вологи найменше значення стираності таблеток забезпечував неусилін UFL-2 (0,08 \%), за ним розташувався кремнію діоксид колоїдний безводний $(0,11 \%)$, які мали перевагу над неусиліном US-2 (0,13 \%) та магнію карбонатом легким $(0,18 \%)$.

Вплив вивчених фракторів на стійкість таблеток до роздавлювання $\left(\mathrm{y}_{9}\right)$ ілюструє такий ряд переваг: A > D $>$ B > C. За допомогою діаграм на рисунку 3 відображено вплив рівнів найбільш значущого фрактора А (наповнювачі), на стійкість таблеток до роздавлювання.

За даними рисунка 3 видно, що найбільшою стійкістю до роздавлювання володіла серія таблеток, які в своєму складі містили сахарозу (115,2 Н). Менш міцними були таблетки, до складу яких входили лактози моногідрат (100,2 Н), МКЦ 101 (79,3 Н) та МКЦ $102(70,8$ H). У загальному можна зазначити, що в даному експерименті всі серії таблеток на основі екстрактів мальви лісової і подорожника ланцетолистого мали високу стійкість до роздавлювання.

Ранжований ряд переваг впливу зв'язуючих речовин на стійкість досліджуваних таблеток до роздавлювання має такий вигляд: 5 \% крохмальний клейстер (112,5 Н), 5 \% спиртовий розчин ГПМЦ $(94,4$ Н), $5 \%$ розчин МЦ-15 $(85,5 \mathrm{H}), 5$ \% спиртовий розчин поліплаздону К-25 (73,1 H).

Найбільш стійкими до роздавлювання були таблетки, які містили в своєму складі розпушувач поліплаздон XL-10 (104,2 H), який мав переваги над нат- рію карбоксиметилкрохмалем (101,9 Н), крохмалем картопляним $(81,8$ Н) і натрію кроскармелозою $(77,7 \mathrm{H})$.

Вплив регуляторів вологи на стійкість таблеток до роздавлювання можна проілюструвати таким рядом переваг: неусилін US-2 (100,7 H), неусилін UFL-2 $(94,7$ H), магнію карбонат легкий $(86,9$ H), кремнію діоксид колоїдний безводний (83,2 H).

Ранжований ряд переваг впливу якісних фракторів на розпадання досліджуваних таблеток $\left(\mathrm{y}_{10}\right)$, має такий вигляд: $\mathrm{A}>\mathrm{C}>\mathrm{D}>$ res > B. Вплив найбільш значущого фрактора A на час розпадання таблеток відображено за допомогою діаграм на рисунку 4.

3 даних рисунка 4 видно, що найменший час розпадання був у таблеток, які містили сахарозу (21,2 хв) та лактози моногідрат (30,8 хв), а найбільший - у таблеток, до складу яких входили МКЦ 101 (52,1 хв) та МКЦ 102 (57,9 хв).

Найшвидше розпадалися таблетки, до складу яких входив кремнію діоксид колоїдний $(26,1)$, який має суттєві переваги над іншими регуляторами вологи: неусіліном UFL-2 (44,4 хв), неусиліном US-2 (44,7 хв) та магнію карбонатом основним (46,8 хв).

Вплив зв'язуючих речовин на розпадання таблеток на основі екстрактів мальви лісової і подорожника ланцетолистого можна проілюструвати таким рядом переваг: 5 \% розчин МЦ-15 (33,3 хв), 5 \% крохмальний клейстер $(35,2$ хв), $5 \%$ спиртовий розчин плаздону К-25 (41,7 хв), 5 \% спиртовий розчин ГПМЦ (51,9 хв).

Ранжований ряд переваг для розпушувачів за їх впливом на розпадання досліджуваних таблеток має такий вигляд: натрію карбоксиметилкрохмаль (34,0 хв), натрію кроскармелоза (37,4 хв), крохмаль картопляний (41,6 хв), поліплаздон XL-10 (48,9 хв).

У загальному результати експерименту показали, що у всіх серіях процес розпадання таблеток перевищував 15 хв, тому при плануванні наступного етапу досліджень особливу увагу слід приділити тим ДР, які

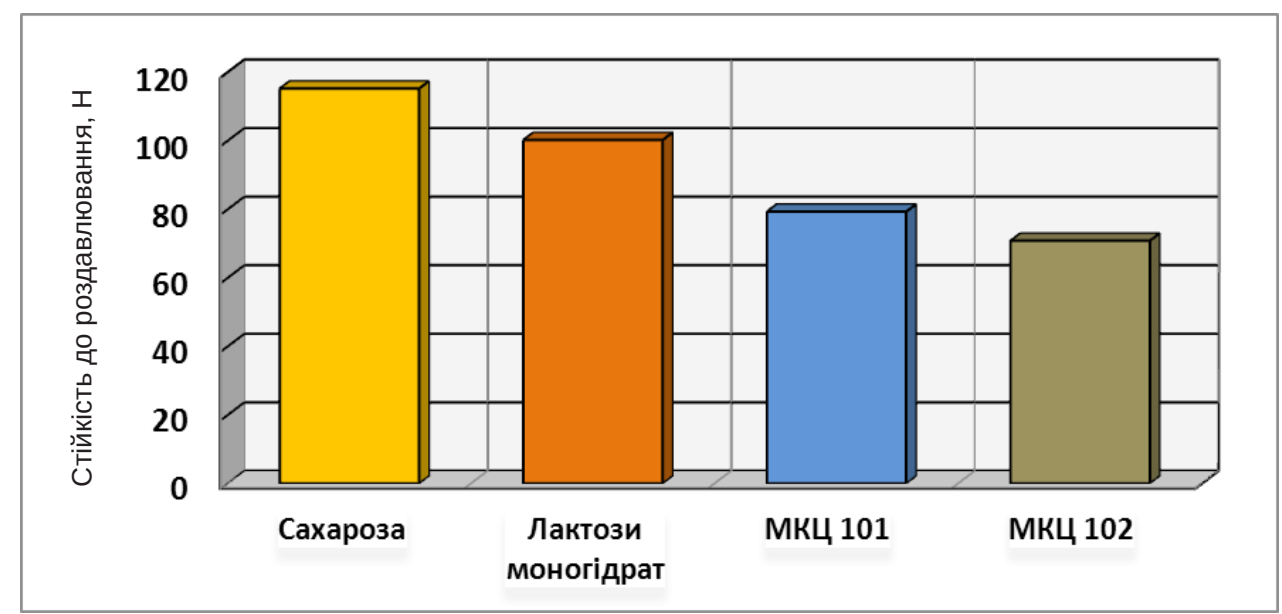

Рис. 3. Вплив наповнювачів на стійкість таблеток на основі екстрактів мальви лісової і подорожника ланцетолистого до роздавлювання.

ISSN 2312-0967. Фармацевтичний часопис. 2018. № 3 
Фармацевтична технологія, біофармація, гомеопатія Pharmaceutical technology, biopharmacy, homeopathy

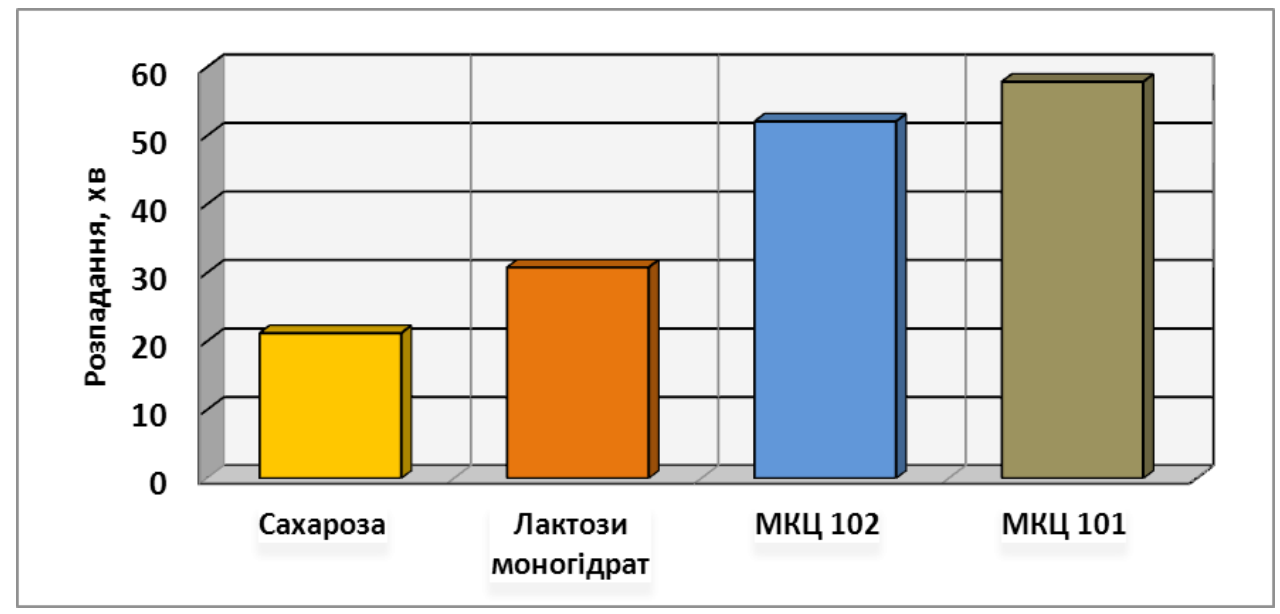

Рис. 4. Вплив наповнювачів на розпадання таблеток на основі екстрактів мальви лісової і подорожника ланцетолистого.

позитивно впливали на даний показник в цьому експерименті.

Вплив вивчених фракторів на стійкість таблеток на основі екстрактів мальви лісової і подорожника ланцетолистого до вологи $\left(\mathrm{y}_{11}\right)$ проявлявся таким чином: $\mathrm{A}>\mathrm{C}>\mathrm{B}>$ res $>\mathrm{D}$. Залежність стійкості таблеток до вологи від виду наповнювача (фактора A) відображено на рисунку 5.

Як показали результати досліджень, найбільш стійкими до вологи були таблетки, до складу яких входили лактози моногідрат (6,0%), також непогані результати отримано при використанні МКЦ 101 (6,7 \%) та МКЦ 102 (6,8 \%); найбільшу кількість вологи поглинули таблетки, до складу яких входила сахароза (10,0 \%).

Вплив регуляторів вологи на стійкість таблеток на основі екстрактів мальви лісової і подорожника ланцетолистого до вологи можна проілюструвати таким рядом переваг: неусилін US-2 (7,0 \%), неусилін UFL2 (7,3\%), магнію карбонат легкий (7,5\%), кремнію діоксид колоїдний безводний $(7,7 \%)$.
Ранжований ряд переваг для розпушувачів за їх впливом на стійкість таблеток до вологи має такий вигляд: натрію кроскармелоза (7,21 \%), натрію карбоксиметилкрохмаль (7,22 \%), крохмаль картопляний (7,38 \%), поліплаздон XL-10 (7,66 \%).

Вплив зв'язуючих речовин на стійкість таблеток до вологи можна проілюструвати таким рядом переваг: 5 \% крохмальний клейстер (7,20 \%), 5 \% розчин МЦ15 (7,28 \%), 5 \% спиртовий розчин ГПМЦ (7,47\%), 5 \% спиртовий розчин плаздону К-25 (7,51 \%).

Проведені дослідження дозволили прослідкувати як впливає природа кожної ДР на основні показники якості таблеток на основі екстрактів мальви лісової і подорожника ланцетолистого. На даному етапі експерименту отримано позитивні результати за багатьма показниками, однак встановлено, що ні в одній групі ДР немає єдиного «лідера», який би покращував усі відгуки. Тому ми застосували фрункцію бажаності, за допомогою якої отримані первинні значення найбільш важливих показників було переведено в безрозмірні величини (рис. 6), враховуючи результа-

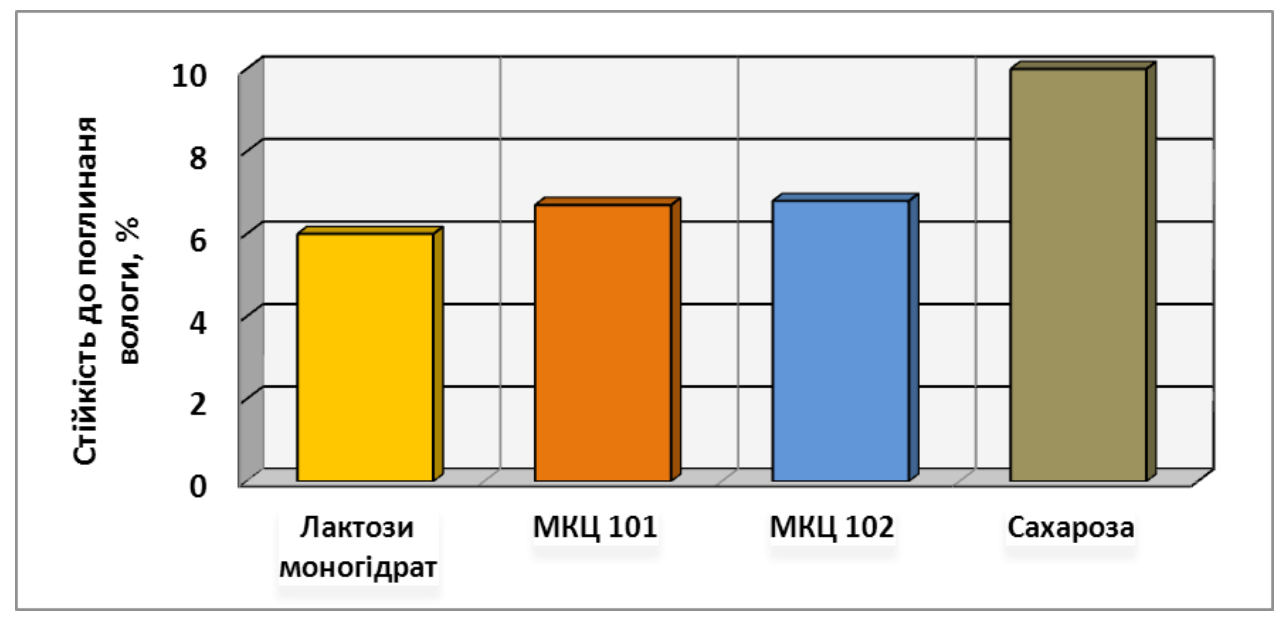

Рис. 5. Вплив наповнювачів на стійкість таблеток на основі екстрактів мальви лісової і подорожника ланцетолистого до вологи.

ISSN 2312-0967. Pharmaceutical review. 2018. № 3 
Фармацевтична технологія, біофармація, гомеопатія Pharmaceutical technology, biopharmacy, homeopathy

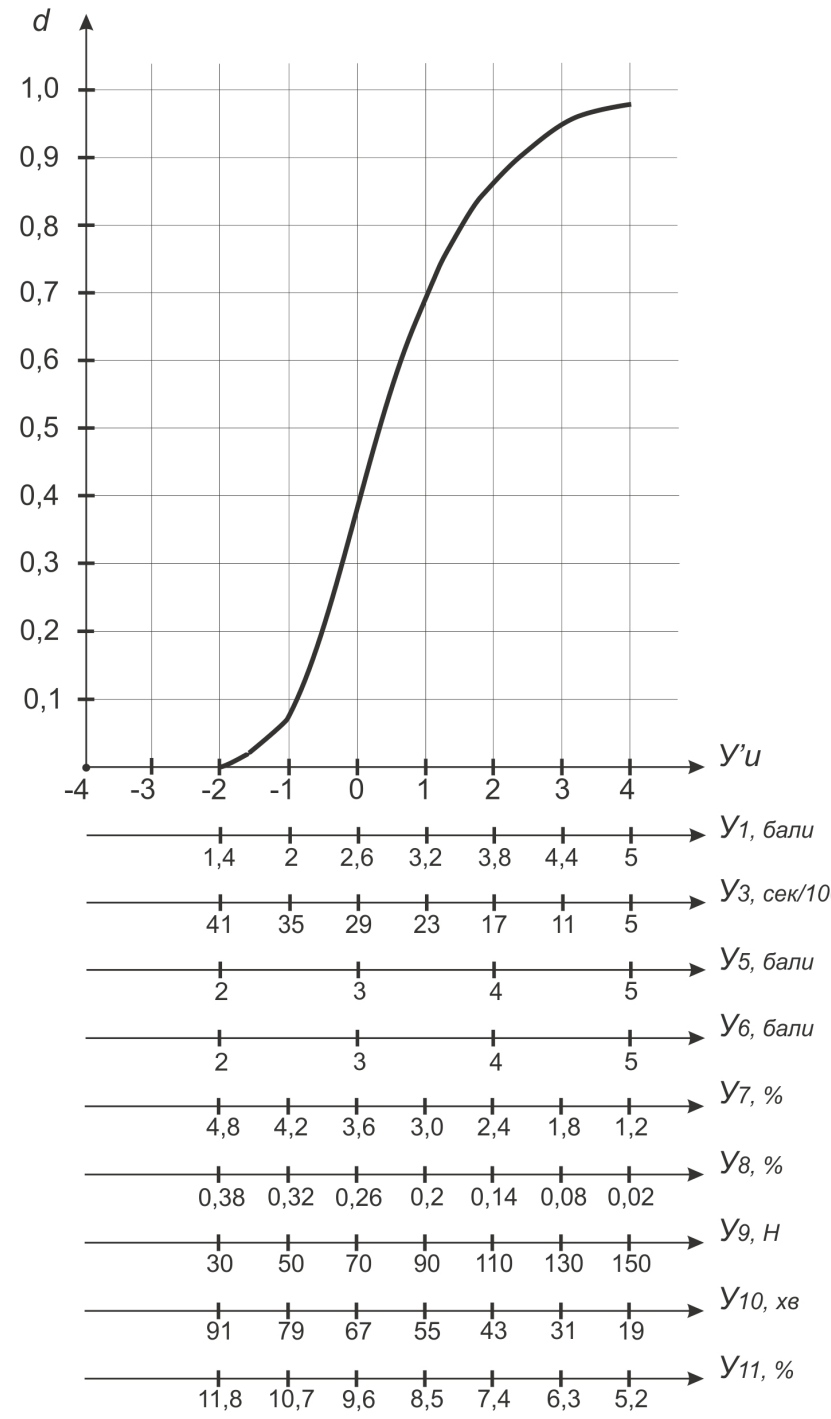

Рис. 6. Функція бажаності.

ти, описані в попередній публікації [1]. Це дозволило узагальнити вплив різних рівнів фракторів на досліджувані показники і визначити лідера у кожній групі ДР. Переведення первинних результатів в безрозмірні величини проводили за методикою, яка описана в монографрії [7].

За впливом на узагальнений показник - функцію бажаності (D) вивчені фрактори можна розмістити в такій послідовності: A > B > res > D > C. Результати експерименту показали, що найбільш значущий вплив на узагальнений показник мають фрактори A i В, тобто природа наповнювача та розпушувача.

Із групи наповнювачів найкращі результати було отримано при використанні МКЦ $101(0,70)$, за нею за позитивним впливом на фрункцію бажаності можна розмістити МКЦ $102(0,65)$ та лактози моногідрат $(0,65)$; на останньому місці знаходиться сахароза
$(0,47)$. Отже, в наступних дослідженнях як наповнювач раціонально використовувати МКЦ 101.

За впливом на узагальнений показник розпушувачі можна розмістити таким чином: поліплаздон XL-10 $(0,74)$, натрію карбоксиметилкрохмаль $(0,64)$, натрію кроскармелоза $(0,60)$, крохмаль картопляний $(0,51)$. Враховуючи те, що час розпадання отриманих таблеток перевищував 15 хв, що не відповідає фрармакопейним нормам, було прийнято рішення для подальших досліджень включити два дезінтегранти в експеримент: поліплаздон XL-10 та натрію карбоксиметилкрохмаль.

Найбільше значення фрункції бажаності отримували при використанні 5 \% крохмального клейстеру $(0,70)$ як зв'язуючого розчину, який було відібрано для подальших досліджень.

Як регулятор вологи найкращі характеристики за впливом на фрункцію бажаності мав кремнію діоксид колоїдний безводний $(0,70)$, за ним стоїть неусилін US-2 $(0,61)$, а також неусилін UFL-2 $(0,60)$; на останньому місці - магнію карбонат легкий $(0,56)$. Враховуючи те, що до складу таблеток входить доволі високий вміст сухих екстрактів, які є гігроскопічними речовинами, на наступному етапі дослідження доцільним $€$ вивчення впливу одразу двох вологорегуляторів - кремнію діоксиду колоїдного безводного та неусиліну US-2.

Отже, на підставі аналізу результатів статистичної оброки, для подальших досліджень при розробці складу і технології таблеток на основі екстрактів мальви лісової і подорожника ланцетолистого обрано такі допоміжні речовини: МКЦ 101, поліплаздон XL-10, натрію карбоксиметилкрохмаль, кремнію діоксид колоїдний безводний, неусилін US-25 і 5 \% крохмальний клейстер.

Висновки. 1. За допомогою чотирифракторного експерименту - греко-латинського квадрату встановлено вплив 4-х якісних фракторів на основні показники якості таблеток на основі сухих екстрактів мальви лісової і подорожника ланцетолистого.

2. Побудовані ранжовані ряди переваг впливу ДР на 6 відгуків (показників) таблеток на основі сухих екстрактів мальви лісової та подорожника ланцетолистого. Вивчено вплив 16-ти ДР на однорідність маси таблеток, їх стираність і стійкість до роздавлювання, а також розпадання таблеток.

3. На основі отриманих результатів обрано кращі ДР для розробки складу і технології нового комбінованого таблетованого лікарського засобу на основі сухих екстрактів мальви лісової і листя подорожника ланцетолистого методом вологої грануляції, а саме: МКЦ 101, поліплаздон XL-10, натрію карбоксиметилкрохмаль, кремнію діоксид колоїдний безводний, неусилін US-25, 5 \% крохмальний клейстер.

ISSN 2312-0967. Фармацевтичний часопис. 2018. № 3 


\title{
ОБОСНОВАНИЕ ВЫБОРА ВСПОМОГАТЕЛЬНЫХ ВЕЩЕСТВ ДЛЯ ПОЛУЧЕНИЯ ТАБЛЕТОК НА ОСНОВЕ ЭКСТРАКТОВ МАЛЬВЫ ЛЕСНОЙ И ПОДОРОЖНИКА ЛАНЦЕТОЛИСТНОГО
}

\author{
С. Я. Белейㅁ, Т. А. Грошовый², Н. Н. Белей² \\ ООО «Тернофрарм»1, Тернополь \\ ГвУЗ «Тернопольский государственный медицинский университет имени И. Я. Горбачевского \\ МЗ Украины»² \\ beley@tdmu.edu.ua
}

Цель работы. Изучить влияние фрармацевтических фракторов на некоторые показатели качества таблеток с целью выбора лучших вспомогательных веществ для разработки состава и технологии нового комбинированного таблетированного лекарственного средства на основе сухих экстрактов мальвы лесной и листьев подорожника ланцетолистного методом влажной грануляции.

Материалы и методы. Основные действующие вещества - сухие экстракты мальвы лесной и листьев подорожника ланцетолистного, 16 вспомогательных веществ, объединенных в 4 группы фрармацевтических фракторов.

Таблетки получали методом влажной грануляции. Исследование влияния вспомогательных веществ на такие показатели, как однородность массы, распадаемость, истираемость и устойчивость к раздавливанию таблеток проводили в соответствии с требованиями ГФУ, 2 издания. Также изучали зависимость устойчивости таблеток к влаге от фрармацевтических фракторов.

Результаты и обсуждение. Статья посвящена изучению влияния фрармацевтических фракторов на некоторые показатели качества таблеток на основе сухих экстрактов цветков мальвы лесной и листьев подорожника ланцетолистного. С помощью четырехсакторного эксперимента - греко-латинского квадрата установлено влияние 4-х качественных факторов на основные показатели качества таблеток на основе сухих экстрактов мальвы лесной и подорожника ланцетолистного. Построены ранжированные ряды преимущества для влияния вспомогательных веществ на 6 отзывов (показателей качества таблеток). Изучено влияние 16-ти вспомогательных веществ на однородность массы таблеток, их истираемость и устойчивость к раздавливанию, а также распадаемость и стойкость таблеток к влаге.

Выводы. На основе полученных результатов были выбраны лучшие вспомогательные вещества для разработки состава и технологии нового комбинированного таблетированного лекарственного средства на основе сухих экстрактов мальвы лесной и листьев подорожника ланцетолистного методом влажной грануляции, а именно: МКЦ 101, полиплаздон XL-10, натрия карбоксиметилкрахмал, кремния диоксид коллоидный, неусилин US-25, 5 \% крахмальный клейстер.

Ключевые слова: фрармацевтические фракторы; вспомогательные вещества; показатели качества; таблетки; экстракты мальвы лесной и подорожника ланцетолистного.

\section{SUBSTANTIATION OF SELECTION OF EXCIPIENTS FOR OBTAINING TABLETS BASED ON MALVA SYLVESTRIS L. AND PLANTAGO LANCEOLATA L. DRY EXTRACTS}

\author{
S. Ya. Beley ${ }^{1}$, T. A. Hroshovyi ${ }^{2}$, N. M. Beley ${ }^{2}$ \\ LLC "Ternofarm"1 \\ I. Horbachevsky Ternopil State Medical University² \\ beley@tdmu.edu.ua
}

The aim of the work. Study of the pharmaceutical factors influence on some quality indicators of the tablets in order to selection of the best excipients for the development of the composition and technology of new complex tableted medicine preparation based on Malva sylvestris and Plantago lanceolata L. leaves dry extracts obtained by method of wet granulation.

Materials and Methods. The main active substances are dry extracts of Malva sylvestris and Plantago lanceolata leaves, 16 excipients combined into 4 groups of pharmaceutical factors. The tablets were obtained by the method of wet granulation. Investigation of the influence of excipients on the uniformity of tablets weight, friability, tablets resistance for crushing, and disintegration of tablets in accordance with the requirements of the SPF, second editions, were carried out. The stability of tablets on moisture was studied too.

Results and Discussion. The article is devoted to the study of the influence of pharmaceutical factors on some quality indicators of the tablets based on the Malva sylvestris $L$. and Plantago lanceolata $L$. dry extracts. The influence of 4 qualitative factors on the main indicators of the quality of tablets based on the Malva sylvestris L. and Plantago lanceolata

ISSN 2312-0967. Pharmaceutical review. 2018. № 3 
Фармацевтична технологія, біофармація, гомеопатія

Pharmaceutical technology, biopharmacy, homeopathy

L. dry extracts have been studied with using the mathematical planning of the experiment (4x4 Greek-Latin square). The ranging rows of the advantages for excipients influence on the 6 indicators of the tablets were constructed. The influence of 16 excipients on the uniformity of the tablets weight, friability, tablets resistance for crushing, and disintegration of the tablets and stability of tablets on moisture have been investigated.

Conclusions. Based on the obtained results, the best excipients have been selected for the development of the composition and technology of a new complex tableted medicine preparation based on Malva sylvestris and Plantago lanceolata L. dry extracts obtained by method of wet granulation, such as: microcrystalline cellulose MCC 101, polyplazm XL-10, sodium carboxymethyl starch, silicon colloidal dioxide, non-silicone US-25, $5 \%$ starch paste.

Key words: pharmaceutical factors; excipients; quality indicators; tablets; extracts of Malva sylvestris L. and Plantago lanceolata $L$.

\section{Список літератури}

1. Beley S. Ya. Investigation of the pharmaceutical factors influence on technological properties of the compression mixture and some quality indicators of tablets based on Malva Sylvestris L. and Plantago lanceolata L. dry extracts / S. Ya. Beley, T. A. Hroshovyi, N. M. Beley // Фармацевтичний часопис. - 2017. - №. 4. С. 41-49.

2. Al-Jumaily E. F. Extraction and purification of Tannins from Plantago lanceolata L. and assessment their antibacterial activity on pathogenesis of enteropathogenic E.Coli in vitro and in vivo / E. F. Al-Jumaily, H. A. Abdul-Ratha, R. H. Raheema // An International Peer-Reviewed Journal. - 2012. - Vol. 1, No. 1. - P. 17-21.

3. Assessment report on Plantago lanceolata L., folium based on Article 16d (1), Article $16 f$ and Article 16h of Directive 2001/83/EC as amended (traditional use). European Medicines Agency, EMA/HMPC/437859/2010 Committee on Herbal Medicinal Products (HMPC) 2012. 24 p.

\section{References}

1. Beley SYa, Hroshovyi TA, Beley NM. [Investigation of the pharmaceutical factors influence on technological properties of the compression mixture and some quality indicators of tablets based on Malva Sylvestris L. and Plantago lanceolata L. dry extracts]. Farmats zhurn. 2017;4: 41-9. Ukrainian.

2. Al-Jumaily EF, Abdul-Ratha HA, Raheema RH. Extraction and purification of Tannins from Plantago lanceolata $L$. and assessment their antibacterial activity on pathogenesis of enteropathogenic E.Coli in vitro and in vivo. An International Peer-Reviewed Journal. 2012;1: 17-21.

3. Assessment report on Plantago lanceolata L., folium based on Article 16d (1), Article $16 \mathrm{f}$ and Article 16h of Directive 2001/83/EC as amended (traditional use). European Medicines Agency, EMA/HMPC/437859/2010 Committee on Herbal Medicinal Products (HMPC) 2012; 24.

4. Seyed Mehdi Razavi, Gholamreza Zarrini, Ghader Molavi. Bioactivity of Malva Sylvestris L., medicinal plant from
4. Bioactivity of Malva Sylvestris L., medicinal plant from Iran / Seyed Mehdi Razavi, Gholamreza Zarrini, Ghader Molavi [et al.] // Iranian Journal of Basic Medical Sciences. - 2011. - Vol. 14, No. 6. - P. 574-579.

5. Chiclana C. F. Actividad Antiinflamatoria Local de Malva sylvestris L. (Malvaceae) en el Edema Inducido por Carragenina en Ratas / C. F. Chiclana, A. Enrique, A. E. Consolini // Latin American Journal of Pharmacy. - 2009. - No. 28 (2). - P. 275-278.

6. Державна Фармакопея України / Держ. п-во «Український науковий фрармакопейний центр якості лікарських засобів». - 2-е вид. - Допов. 3. - Харків : Держ. п-во «Український науковий фрармакопейний центр якості лікарських засобів». - 2014. - 724 с.

7. Математичне планування експерименту при проведенні наукових досліджень в фрармації / [Грошовий Т. А., Марценюк В. П., Кучеренко Л. І. та ін.]. Тернопіль : ТДМУ. - 2008. - 368 с.

Iran. Iranian Journal of Basic Medical Sciences. 2011;6: 574-9.

5. Chiclana CF, Enrique A, Consolini AE. Actividad Antiinflamatoria Local de Malva sylvestris L. (Malvaceae) en el Edema Inducido por Carragenina en Ratas. Latin American Journal of Pharmacy. 2009;28(2): 275-8.

6. State Pharmacopoeia of Ukraine: in 3 vol. State Enterprise "Ukrainian Research Center expert pharmacopoeia quality medicines." - 2nd ed. [Держ. п-во «Український науковий фрармакопейний центр якості лікарських засобів». Державна Фармакопея України: 2-е вид. Допов.] Kharkiv: State Enterprise "Ukrainian Research Center expert pharmacopoeia drug quality"; 2015. Ukrainian.

7. Hroshovyi TA, Martseniuk VP, Kucherenko LI, Vronska LV, Hurieieva CM. Mathematical planning of experiment in pharmacy. [Математичне планування експерименту в орармації] Ternopil: Ternopil State Medical University; 2008. Ukrainian. 